\begin{tabular}{|l|l|}
\hline $\begin{array}{l}\text { Postprint } \\
\text { Version }\end{array}$ & 1.0 \\
\hline Journal website & \\
\hline Pubmed link & \\
\hline DOI
\end{tabular}

This is a NIVEL certified Post Print, more info at http://www.nivel.eu

\title{
Patiënten met multimorbiditeit en polyfarmacie
}

\author{
SCHELLEVIS, F.G., WIND, A.W.
}

\section{INLEIDING}

In de dagelijkse praktijk zijn er steeds meer patiënten die meerdere gezondheidsproblemen hebben. Dit heeft deels te maken met de toename van het absolute aantal oudere patiënten, die vaker dan jongeren chronische ziekten hebben, maar ook met het feit dat chronische ziekten in een vroeger stadium gediagnosticeerd worden en deze mensen langer in leven blijven dan vroeger dankzij de huidige diagnostische mogelijkheden en behandelingsopties. Dit gaat onvermijdelijk gepaard met een verhoogde kans op verscheidene ziekten en op het gebruik van diverse geneesmiddelen. Bij een patiënt met meerdere problemen verloopt het geneeskundig proces niet wezenlijk anders dan bij een patiënt met één probleem, maar het vergt wel extra alertheid op een aantal aspecten.

\section{BEGRIPSBEPALING}

Met multimorbiditeit wordt bedoeld dat een patiënt aan meerdere ziekten tegelijkertijd lijdt. Meestal gaat het daarbij om chronische ziekten (zowel somatisch als psychiatrisch), maar ook wel om een acute aandoening bij een patiënt die aan een of meer chronische ziekten lijdt. Een andere term is 'comorbiditeit': één of meer andere ziekten naast een al bestaande ziekte. Wij beperken ons hier tot de term multimorbiditeit. Of er sprake is van multimorbiditeit hangt af van de definitie van wat een 'ziekte' is. Hierover zijn de boeken nog niet gesloten (zie ook hoofdstuk 1).

Comorbiditeit en multimorbiditeit staan pas sinds de jaren zestig van de twintigste eeuw in de belangstelling. Feinstein, een Amerikaanse internist en klinisch epidemioloog, introduceerde de term comorbiditeit in 1967, naar aanleiding van een onderzoek waaruit bleek dat de prognose van patiënten met borstkanker slechter was indien deze patiënten bekend waren met nog een chronische ziekte naast de borstkanker. Multimorbiditeit werd voor het eerst gedefinieerd in 1996 door Van den Akker: 'The cooccurrence of multiple chronic or acute diseases and medical conditions within one person.'

Multimorbiditeit komt frequent voor. De schattingen - afhankelijk van de definitie en de 'setting' waarin de metingen plaatsvinden - variëren van twee derde van de patiënten tussen 65 en 74 jaar tot $85 \%$ van de patiënten van 85 jaar en ouder. Het ligt voor de hand dat in de top vijf van meest voorkomende combinaties van chronische ziekten hypertensie vaak voorkomt (zie tabel 13.1) - strikt genomen een risicofactor, maar de meeste mensen gebruiken daarvoor wel geneesmiddelen. Maar ook combinaties met artrose, diabetes mellitus en cataract komen in de top vijf voor.

\section{[TABEL 1]}

De term polyfarmacie wordt meestal gereserveerd voor het gelijktijdig en langdurig gebruik van drie of meer geneesmiddelen. Polyfarmacie houdt geen waardeoordeel in, dus polyfarmacie is geen synoniem van overbehandeling. Van de zelfstandig wonende ouderen gebruikt 35\% drie of meer geneesmiddelen, bij bewoners van verzorgingshuizen is dit percentage nog hoger. Multimorbiditeit en polyfarmacie hangen uiteraard met elkaar samen. Als een patiënt lijdt aan meerdere chronische ziekten, is de kans zeer groot dat deze patiënt langdurig drie of meer verschillende geneesmiddelen gebruikt. 
Schellevis, F.G., Wind, A.W. Patiënten met multimorbiditeit en polyfarmacie. In: H.G.L.M. Grundmeijer;-K. Reenders; G.E.H.M. Rutten (Reds). Het geneeskundig proces. Klinisch redeneren van klacht naar theraplic Maarssen: Elsevier gezondheidszorg, 2009. 329-341

\section{HET BELANG VAN MULTIMORBIDITEIT EN POLYFARMACIE}

Multimorbiditeit en polyfarmacie hebben belangrijke gevolgen voor de medische zorg. Bestaande ziekten kunnen andere ziekten maskeren, de 'standaardzorg' voor de afzonderlijke ziekten kan tegenstrijdigheden opleveren of tot ongewenste combinaties van geneesmiddelen leiden. En vaak zijn meerdere zorgverleners bij de zorg betrokken waardoor het totaaloverzicht over de zorg verloren kan gaan.

Polyfarmacie verhoogt het risico van (ongewenste) bijwerkingen, interacties tussen geneesmiddelen, verminderde therapietrouw en zelfs van een acute ziekenhuisopname.

Multimorbiditeit vergroot de kans op minder goed functioneren, op complicaties van medische behandelingen, op ziekenhuisopnames en op sterfte. Zo blijkt het aantal ziekten samen te hangen met de kans op een ziekenhuisopname vanwege een geneesmiddelgerelateerd probleem, zelfs na correctie voor polyfarmacie (zie tabel 13.2).

\section{[TABEL2]}

\section{MULTIMORBIDITEIT}

\section{Multimorbiditeit en de diagnostiek van ziekten}

Vaak gaan chronische ziekten gepaard met klachten en symptomen waarvan het beloop sterk kan variëren. Bij de ene ziekte kan er sprake zijn van constant bestaande klachten en symptomen, bij de andere van een geleidelijke verergering of van verergeringen afgewisseld met periodes met relatief minder klachten. De klachten waarmee een chronische ziekte gepaard gaat, kunnen het bestaan van een andere ziekte maskeren.

Een man van 78 jaar komt met klachten van duizeligheid op het spreekuur. Hoewel de duizeligheid mogelijk wordt veroorzaakt door een stoornis in het evenwichtsorgaan, zijn andere oorzaken zeker zo waarschijnlijk wanneer je zijn probleemlijst bekijkt: hartfalen, glaucoom, cataract en gonartrose. De man gebruikt een bètablokker, een ACE-remmer en furosemide vanwege zijn hartfalen, bètablokkeroogdruppels vanwege zijn glaucoom en een NSAID vanwege zijn gonartrose. Hij heeft een matige visus, een gestoorde propriocepsis en een verminderde kracht in zijn beenspieren.

Deze casus illustreert het diagnostisch probleem. Het gaat nu niet zozeer om de vraag van welke ziekte er sprake is (zie ook hoofdstuk 6), maar of de klachten moeten worden toegeschreven aan:

- $\quad$ een van de al bestaande ziekten (hartfalen, visusstoornissen, artrose);

- $\quad$ de medicatie (bijwerkingen van bètablokkers, ACE-remmer, NSAID);

- $\quad$ een nieuwe aandoening (bijvoorbeeld een evenwichtsstoornis).

Het is duidelijk dat het stellen van een diagnose in dit geval bemoeilijkt wordt door de reeds bestaande ziekten en medicamenteuze behandeling daarvan. Multimorbiditeit compliceert dus het diagnostisch proces en vraagt om extra alertheid van de arts. Schrijf klachten niet te gemakkelijk toe aan een al bestaande ziekte of behandeling, zeker niet als het om atypische klachten of een atypisch beloop van de klachten gaat.

\section{Multimorbiditeit en de behandeling van ziekten}

Indien een patiënt lijdt aan meerdere chronische ziekten, kan de ene ziekte invloed hebben op (het beloop van) de andere ziekte, maar ook kunnen de behandelingen met elkaar interfereren. Enkele voorbeelden: als een patiënt met een ernstige obstructieve longziekte niet meer dagelijks een wandeling kan maken, zullen de klachten over stijfheid ten gevolge van een artrose in de knie toenemen. Het gebruik van een bètablokker vanwege hypertensie kan het beloop van astma beïnvloeden. En het gebruik van benzodiazepinen vanwege een slaapstoornis kan het risico van vallen verhogen. Het gelijktijdige gebruik van een non-steroïd antiinflammatoir (NSAID) geneesmiddel vanwege reumatoïde artritis en acetylsalicylzuur vanwege een doorgemaakt cerebrovasculair accident kan tot gevaarlijke gastro-intestinale bloedingen leiden. In de eerdergenoemde casus leidt het gebruik van de NSAID mogelijk tot meer klachten van hartfalen; echter, zonder goede pijnstilling loopt deze patiënt waarschijnlijk minder, met alle gevolgen van dien voor zijn dagelijks functioneren. Ook niet-medicamenteuze behandelingen voor verschillende ziekten kunnen met elkaar interfereren, bijvoorbeeld tegenstrijdige dieetadviezen of leefregels.

Voor de behandeling van veel chronische ziekten zijn evidence-based richtlijnen beschikbaar (zie ook de bijlage bij hoofdstuk 7). Maar in deze richtlijnen wordt zelden rekening gehouden met multimorbiditeit, ook omdat hierover nauwelijks evidence bestaat. Dit betekent dat de arts bij de behandeling van patiënten met multimorbiditeit 'maatwerk' moet leveren: voor iedere individuele patiënt systematisch nagaan of en 
Schellevis, F.G., Wind, A.W. Patiënten met multimorbiditeit en polyfarmacie. In: H.G.L.M. Grundmeijer; K. Reenders; G.E.H.M. Rutten (Reds). Het geneeskundig proces. Klinisch redeneren van klacht naar therapie Maarssen: Elsevier gezondheidszorg, 2009. 329-341

op welke wijze het beloop en de behandelingen van de afzonderlijke ziekten met elkaar kunnen interfereren en de voor- en nadelen van de verschillende combinaties van behandelingen afwegen. Bij dit maatwerk vormen herstel en behoud van functie en daarmee kwaliteit van leven vaak een belangrijkere leidraad dan een 'scherpe' behandeling van de ziekten.

\section{Polyfarmacie}

Het tegelijkertijd langdurig gebruiken van meerdere geneesmiddelen, vanwege één of meerdere ziekten, brengt specifieke problemen met zich mee. Daarbij gaat het niet alleen om interacties tussen geneesmiddelen, maar ook om over- en onderbehandeling, de haalbaarheid voor de patiënt zich te houden aan de inname-voorschriften, het medicatiedossier en de afstemming tussen de voorschrijvende artsen.

In het Journal of the American Medical Association stond in 2005 een artikel van een groep onderzoekers die voor een hypothetische patiënte met multimorbiditeit de medicamenteuze behandeling voor alle afzonderlijke ziekten (hypertensie, diabetes mellitus, osteoporose, artrose en chronisch obstructief longlijden), zoals geadviseerd in bestaande richtlijnen, hebben geïnventariseerd. De desbetreffende fictieve patiënte zou twaalf verschillende medicamenten moeten gebruiken, in te nemen in negentien doses op vijf verschillende tijdstippen van de dag.

\section{Interacties}

De meeste geneesmiddelen oefenen hun werking uit via de beïnvloeding van metabole en enzymatische processen in het lichaam. Indien verschillende geneesmiddelen aangrijpen op eenzelfde werkingsmechanisme kan dit een versterkend of remmend effect hebben op de werkzaamheid van die middelen. Hoewel er veel interacties tussen geneesmiddelen bekend zijn, zijn niet alle geneesmiddelen daadwerkelijk getest op interactie met alle andere beschikbare geneesmiddelen. Dit betekent dat de arts alert moet zijn op tot dan toe onbekende interacties bij patiënten die meerdere geneesmiddelen gebruiken.

\section{[Tabel 3]}

Zoals uit tabel 13.3 blijkt, wordt een aantal geneesmiddelen relatief vaak gebruikt door polyfarmaciepatiënten. Bovenaan in de top tien van meest gebruikte geneesmiddelen door deze patiënten staan bloedverdunnende middelen. Daarvan is bekend dat ze vaak interacties geven met andere geneesmiddelen.

Speciale aandacht verdient de farmacokinetiek bij polyfarmacie. Polyfarmacie komt met name bij ouderen voor, bij wie de wijze waarop en de snelheid waarmee het lichaam geneesmiddelen opneemt en uitscheidt anders kunnen verlopen dan bij jongeren. Daarbij gaat het niet alleen om een verminderde nier- of leverfunctie en dus een vertraagde uitscheiding, maar ook om de verdeling van het geneesmiddel over het lichaam (bijvoorbeeld door toename van het vetweefsel) of om veranderingen in de receptoren waarop de geneesmiddelen aangrijpen.

\section{Overbehandeling en onderbehandeling}

Naarmate geneesmiddelen langduriger door een patiënt worden gebruikt, dreigt de 'macht der gewoonte'. Het gebruik van het geneesmiddel wordt routinematig voortgezet, zonder expliciet na te gaan of de indicatie waarvoor de medicamenteuze behandeling was ingezet nog steeds geldig is. Het gebruik van maagzuurremmers is daarvan een goed voorbeeld. Indien de indicatie hiervoor niet meer bestaat, kan polyfarmacie in dat geval wijzen op overbehandeling. De gewoonte om herhaalrecepten uit te schrijven draagt het risico van overbehandeling in zich. Periodieke heroverweging van het voortzetten van de behandeling bij het verlengen van recepten is noodzakelijk om overbehandeling te voorkomen. Soms kan gesproken worden van foutieve behandeling indien een geneesmiddel wordt voorgeschreven ter behandeling van de bijwerkingen van een ander geneesmiddel. Het betekent dat iedere arts bij klachten van een patiënt zich altijd moet afvragen of de klacht niet het gevolg kan zijn van de ingestelde behandeling. Wie dat niet doet, loopt een aanzienlijke kans met de tweede behandeling de bijwerkingen van de eerste behandeling te bestrijden. Hoewel dat soms zinvol is, is het meestal veel zinniger om de eerder ingestelde behandeling te wijzigen.

Polyfarmacie kan ook tot onderbehandeling leiden. Naarmate oudere patiënten meer geneesmiddelen gebruiken, is de kans op onderbehandeling groter omdat de arts terughoudend is om nog méér geneesmiddelen of geneesmiddelen in een hoge dosering voor te schrijven. 
Schellevis, F.G., Wind, A.W. Patiënten met multimorbiditeit en polyfarmacie. In: H.G.L.M. Grundmeijer; K. Reenders; G.E.H.M. Rutten (Reds). Het geneeskundig proces. Klinisch redeneren van klacht naar therapileMaarssen: Elsevier gezondheidszorg, 2009. 329-341

\section{[TABEL 4]}

\section{Haalbaarheid van geneesmiddelengebruik en therapietrouw}

Polyfarmacie, zeker als de verschillende geneesmiddelen in verschillende combinaties op meerdere tijdstippen van de dag ingenomen moeten worden, vergroot de kans op fouten en op therapieontrouw. De maatregelen ter bevordering van de therapietrouw zoals vermeld in hoofdstuk 7 gelden onverkort bij polyfarmacie. Overleg met de patiënt is nodig om het geneesmiddelengebruik en de tijdstippen van inname zo goed mogelijk in te passen in het dagelijks leven. Over het algemeen geldt: hoe minder innamemomenten, hoe hoger de therapietrouw en hoe kleiner de kans op fouten. Overleg met de apotheker en het gebruik van bijvoorbeeld een baxter of waarschuwingsmethoden kunnen behulpzaam zijn.

\section{Afstemming tussen voorschrijvende artsen}

Naarmate patiënten aan meer ziekten lijden, neemt de kans toe dat ook meerdere artsen bij de behandeling zijn betrokken. Iedere arts afzonderlijk is verantwoordelijk voor de door hem voorgeschreven medicatie. Wanneer de patiënt meerdere geneesmiddelen gebruikt, rust op iedere arts afzonderlijk de plicht om bij elke wijziging van de medicatie na te gaan of deze wijziging, uitgaande van alle reeds gebruikte medicamenten, geïndiceerd, werkzaam en doeltreffend is, en of geen onbedoelde schade kan optreden. Zonder dat cijfers hierover bekend zijn, durven wij de stelling te poneren dat artsen te weinig onderling overleggen over de samenstelling van het palet aan geneesmiddelen dat veel mensen dagelijks op advies van verschillende artsen moeten slikken. Een goede samenwerkingsrelatie met een apotheker kan daarbij van grote waarde zijn.

\section{Het medicatiedossier}

De beschikbaarheid van een actueel en volledig overzicht van alle huidige gebruikte geneesmiddelen is een voorwaarde om te kunnen beoordelen of alle geneesmiddelen die een patiënt gebruikt geïndiceerd zijn, of de juiste doses zijn voorgeschreven en of er risico's zijn van interacties of onveilige situaties. In theorie staat het toekomstige elektronisch patiëntendossier (EPD) hiervoor garant. In de huidige situatie blijkt het dossier vaak niet actueel en compleet, tenzij er een koppeling bestaat tussen het medicatiedossier bij de huisarts en in de apotheek. De kans op onvolledige en foutieve gegevens neemt toe naarmate meer overdrachtmomenten in de behandeling van een patiënt optreden (bijvoorbeeld via verwijzing naar een medisch specialist, ontslag uit het ziekenhuis, geneesmiddelenverstrekking via meerdere apotheken). Riskante ontwikkelingen op dit gebied zijn het ontstaan en gebruiken van internetapotheken en poliklinische apotheken.

\section{FARMACOTHERAPIEOVERLEG (FTO)}

De meeste huisartsen in Nederland nemen deel aan een FTO: regelmatig (4-6 keer per jaar) en gestructureerd overleg tussen een groep huisartsen en één of meer apothekers. Hierin kunnen allerlei onderwerpen besproken worden, waarbij vaak ook gekeken wordt naar de voorschrijfcijfers. Dit geeft een goed inzicht in het individuele voorschrijfgedrag van de deelnemende huisartsen. Binnen het FTO wordt vaak ook aandacht besteed aan polyfarmacie. Een gerichte beoordeling van polyfarmacie op patiëntniveau kan het best gebeuren in een apart overleg tussen de huisarts en de apotheker, aan de hand van het medisch dossier.

\section{POLYFARMACIEOVERLEG TUSSEN DE HUISARTS EN DE APOTHEKER}

De apotheker geeft aan welke patiënten 5 of meer middelen gebruiken. Per overleg worden 5-6 patiënten besproken. De huisarts gaat per patiënt na welke indicaties aanwezig zijn.

Samen beantwoorden de huisarts en de apotheker de volgende vragen:

- Wat moet erbij?

- Wat wordt ingenomen?

- Wat is overbodig?

- Welke bijwerkingen zijn aanwezig?

- Welke klinisch relevante interacties zijn te verwachten?

- Wordt het middel correct gegeven of moet de dosis of doseerfrequentie anders?

De huisarts bespreekt de medicatiewijzigingen met de patiënt. 
Schellevis, F.G., Wind, A.W. Patiënten met multimorbiditeit en polyfarmacie. In: H.G.L.M. Grundmeijer; K. Reenders; G.E.H.M. Rutten (Reds). Het geneeskundig proces. Klinisch redeneren van klacht naar theraplic Maarssen: Elsevier gezondheidszorg, 2009. 329-341

\section{DE PATIËNT}

Bij de gevolgen van multimorbiditeit en polyfarmacie voor het geneeskundig proces speelt de patiënt een niet te onderschatten rol.

\section{Ervaringsdeskundigheid}

Er is in de literatuur weinig informatie beschikbaar over de invloed die elke specifieke combinatie van ziekten heeft op het leven en de beleving van die patiënten. Daarom is de eigen ervaringsdeskundigheid van patiënten met multimorbiditeit van groot belang. Als arts is het dan ook uitermate nuttig om de patiënt te laten vertellen over zijn ervaringen met de ziekten waaraan hij lijdt, met de gevolgen daarvan en met de behandelingen. Deze kennis is behulpzaam bij het interpreteren van klachten en symptomen en ook bij het inschatten van de haalbaarheid van behandelingen.

\section{Besluitvorming over behandeling}

Bij patiënten met multimorbiditeit is de keuze voor een behandeling vaak niet eenduidig. Een keuze voor een behandeling van de ene ziekte heeft mogelijk negatieve gevolgen voor een andere ziekte. Het voorschrijven van een nieuw geneesmiddel kan weliswaar de klachten doen verminderen, maar vergroot de kans op bijwerkingen van een ander geneesmiddel. Het gaat in de meeste gevallen om chronische ziekten waarbij genezing niet aan de orde is, hooguit de beïnvloeding van het beloop van de ziekten. De keuze voor een behandeling moet dan ook gebaseerd worden op een afweging van prioriteiten. Wat vindt de patiënt het belangrijkste? Een geneesmiddel gaan gebruiken dat een vermindering van de klachten geeft, maar de kans op complicaties doet toenemen? Het is de taak van de arts om de patiënt voldoende informatie te geven om vervolgens in een gezamenlijk gesprek een goede afweging te kunnen maken. Juist in het geval van patiënten met meerdere medische problemen kan dat lastig zijn. Het is belangrijk om daarbij te verifiëren dat de patiënt het goed begrepen heeft. Een deel van de patiënten met multimorbiditeit zal moeite hebben om alle informatie in zich op te kunnen nemen, of zelfs wilsonbekwaam zijn. In dat geval is zorgvuldig overleg met de naasten aangewezen.

\section{Coördinatie van de zorg door de patiënt}

Patiënten met multimorbiditeit ervaren zelf heel duidelijk hoe gebrekkig de organisatie van de zorg is.

'Ik vraag me weleens af wat de artsen nu eigenlijk met je gegevens doen. Je moet steeds weer voor je eigen belangen opkomen. Steeds bijhouden wat je op dat moment gebruikt. Want hun administratie loopt hopeloos achter.'

'Specialisten voor de verschillende ziektes zijn nauwelijks van elkaars handelen op de hoogte. Zelfs binnen hetzelfde ziekenhuis weten ze van elkaar niet wat ze doen. Zelfs binnen dezelfde afdeling. Steeds opnieuw je verhaal doen en vertellen welke medicijnen je hebt.'

'Door meerdere ziekten heb je verschillende specialisten en ziekenhuizen. Informatie komt vaak te laat of wordt niet doorgegeven. Dus je zult alles zelf in de gaten moeten houden. Accepteer maar gewoon dat men de informatie vaak niet heeft. Leer tolerant te zijn.'

Bron: Heijmans, e.a., 2003.

Sommige patiënten zullen de coördinatie van hun eigen zorg in handen nemen, anderen zijn daartoe minder goed in staat. Maar patiënten willen graag kunnen terugvallen op een zorgverlener die het overzicht heeft en hen kan ondersteunen bij het maken van keuzes.

\section{ORGANISATIE VAN DE ZORG}

Uit het voorgaande blijkt dat de medische zorg voor patiënten met multimorbiditeit en polyfarmacie aan andere, aanvullende eisen moet voldoen in vergelijking met de medische zorg voor patiënten met minder complexe problemen. Er kan immers niet teruggevallen worden op evidence-based richtlijnen, er moet 'zorg op maat' verleend worden en er zijn meestal meerdere hulpverleners bij de zorg betrokken.

Zowel in het ziekenhuis als daarbuiten groeit de rol van gespecialiseerde verpleegkundigen. Er zijn specialisaties op allerlei gebieden, waaronder geriatrie, hartfalen, longziekten, diabetes en reumatologie. Deze gespecialiseerde verpleegkundigen werken in toenemende mate zelfstandig, aan de hand van protocollen. Zij worden (veelal op de achtergrond) aangestuurd door artsen. 
Schellevis, F.G., Wind, A.W. Patiënten met multimorbiditeit en polyfarmacie. In: H.G.L.M. Grundmeijer; K. Reenders; G.E.H.M. Rutten (Reds). Het geneeskundig proces. Klinisch redeneren van klacht naar theraplic Maarssen: Elsevier gezondheidszorg, 2009. 329-341

\section{Regie over de zorg}

De huidige organisatie van de medische zorg is zoals gezegd niet ingesteld op patiënten met multimorbiditeit en polyfarmacie. Met name de medisch-specialistische zorg is 'orgaanspecifiek' georganiseerd en gericht op patiënten met één ziekte. Daarbij maken patiënten met multimorbiditeit ook veelvuldig gebruik van eerstelijns paramedische zorg, verpleegkundige zorg, thuiszorg en andere zorgvoorzieningen. De verantwoordelijkheid voor de zorg voor patiënten met multimorbiditeit ligt momenteel nog niet in handen van één zorgverlener. Dat moet veranderen, want de kans op ongewenste of onveilige situaties en op inefficiëntie en 'langs elkaar heen werken' is groot.

De huisarts is de geschiktste kandidaat om de regie over de zorg voor patiënten met multimorbiditeit en polyfarmacie te voeren, samen met de patiënt en eventueel diens familie. De huisarts kent de patiënt en diens familie vaak al een langere periode, heeft overzicht over de verschillende problemen en aandoeningen en beschikt over het complete medisch dossier en medicatiedossier. Dit betekent dat de huisarts, in overleg met de patiënt en eventuele mantelzorgers, de zorg van alle betrokken medische en niet-medische zorgverleners aanstuurt en op elkaar afstemt, zowel organisatorisch als inhoudelijk. Voor patiënten die zijn opgenomen in het verpleeghuis is de verpleeghuisarts hiervoor de aangewezen persoon en in de tweede lijn zal een klinisch geriater of een internist deze rol op zich nemen.

\section{Casemanagement}

Onder de regiefunctie van artsen valt niet het coördineren van de dagelijkse zorg. Die taak wordt overgelaten aan de patiënt zelf of aan de familie. Als een van hen hier niet toe in staat is of als de zorg te ingewikkeld wordt, moet er een casemanager benoemd worden. Huisartsen zijn hier medeverantwoordelijk voor. Een casemanager is een medewerker die functioneert op hbo-niveau, zoals de praktijkondersteuner en de praktijkverpleegkundige. Het kan ook een verpleegkundige van een thuiszorgorganisatie zijn, of van een GGZ-instelling (bijvoorbeeld bij patiënten met dementie). Het aansturen van de casemanager is een taak van de huisarts. Dit vergt regelmatig contact, ook met een casemanager van buiten de eigen praktijk.

\section{Informatievoorziening}

Voor het adequaat regisseren van de zorg is actuele en volledige informatie een vereiste, niet alleen over de gebruikte medicatie, maar ook over welke zorgverleners bij de zorg voor de patiënt betrokken zijn, welke zorg verleend wordt en wat de uitkomsten daarvan zijn. Van oudsher voelen huisartsen zich verantwoordelijk voor het beheer van het dossier van hun patiënten. Als er zorg door anderen wordt verleend, is de huisarts voor de volledigheid van het dossier afhankelijk van de berichtgeving daarover. Op alle hulpverleners rust dan ook de plicht om tijdige en bruikbare informatie aan de huisarts te verstrekken.

Mogelijk biedt het toekomstige elektronisch patiëntendossier de gewenste actualiteit en volledigheid; tot de realisering daarvan ligt het beheer van het zorgdossier voor niet-geïnstitutionaliseerde patiënten met multimorbiditeit in handen van de huisarts.

De huisarts maakt in zijn HIS (huisartsinformatiesysteem, zie hoofdstuk 11) gebruik van een episodelijst. Daarin staan overzichtelijk de verschillende aandoeningen van de patiënt. Deze lijst geeft echter geen inzicht in de ervaren last van de aandoening en de eventuele beperkingen in het functioneren van de patiënt. Indien iemand een CVA gehad heeft, kan hij hierdoor ernstig gehandicapt zijn, maar ook volledig onafhankelijk zijn in zijn functioneren. Bij dergelijke aandoeningen is het van belang om de beperking te benoemen bij het probleem, bijvoorbeeld: '2005 CVA met hemiparese rechts en motorische afasie'.

\section{Sturing}

Hoe kan een huisarts sturing geven aan het zorgproces? Allereerst is het nodig om overzicht te hebben van de verschillende gebieden waarop zich problemen voordoen en welke hulpverleners bij de zorg betrokken zijn. Tevens moet worden beoordeeld of de zorg tegemoetkomt aan de wensen van de patiënt of dat er misschien hiaten in de hulpverlening zijn. De betrokkenen moeten het eens zijn over de globale behandeldoelen: gaat het om functieherstel, om het voorkómen van verslechtering of is er sprake van een terminale situatie waarin achteruitgang onvermijdelijk is? Welke problemen moeten als eerste aangepakt worden omdat ze de andere mogelijke hulp belemmeren? Als iemand bijvoorbeeld veel pijn heeft, zal het mobiliseren moeizaam zijn en moet eerst de pijn verder bestreden worden. Wat zijn voor de patiënt zelf de belangrijkste doelstellingen? Voor de een staan sociale contacten bovenaan, een ander vindt onafhankelijkheid het belangrijkst. Alle betrokken hulpverleners zouden bekend moeten zijn met de wensen van de patiënt en hun rol daarin onderling moeten afstemmen. 
Schellevis, F.G., Wind, A.W. Patiënten met multimorbiditeit en polyfarmacie. In: H.G.L.M. Grundmeijer;-K. 7 Reenders; G.E.H.M. Rutten (Reds). Het geneeskundig proces. Klinisch redeneren van klacht naar therapieMaarssen: Elsevier gezondheidszorg, 2009. 329-341

Een manier om deze problematiek het hoofd te bieden is het werken met een zorgplan. Een zorgplan is een hulpmiddel om een overzicht te hebben van de verschillende actuele probleemgebieden, de bijbehorende behandeldoelen, de verschillende hulpverleners en hun aanpak. Het zorgplan is te vergelijken met het beleidsplan (zie hoofdstuk 8), maar is veelomvattender omdat verschillende probleemgebieden erin terug te vinden zijn. Tabel 13.5 geeft een voorbeeld van hoe een zorgplan eruit kan zien.

\section{[TABEL 5]}

In tabel 13.5 is het SFMPC-model gebruikt. Bij het SFMPC-model worden de problemen onderverdeeld in vaste aandachtsgebieden: het Somatische, Functionele, Maatschappelijke, Psychische en Communicatieve domein. Deze indeling helpt om geen aspecten over het hoofd te zien. Vervolgens wordt, samen met de patiënt en diens naasten, een prioritering aangebracht in deze probleemvelden. De belangrijkste problemen worden in het zorgplan opgenomen, waarna de behandeldoelen, de acties (wie doet wat?) en het tijdstip voor evaluatie worden vastgelegd.

Bij patiënten met multimorbiditeit is de behandeling en begeleiding gericht op het behoud of herstel van functies. Het is voor de patiënt van belang dat de arts helpt om de functionele achteruitgang tot staan te brengen respectievelijk te vertragen, en meedenkt in hoe de beperkingen gecompenseerd kunnen worden. Hulpmiddelen kunnen dan uitkomst bieden, maar ook training en psychische begeleiding.

\section{Multidisciplinaire samenwerking}

Bij de uitvoering van de zorg rondom een patiënt met multimorbiditeit wordt gebruikgemaakt van de expertise van verschillende hulpverleners. Samenwerking (zie hoofdstuk 10) is bij ouderen met multimorbiditeit absoluut noodzakelijk. Het liefst binnen een vast team, zoals men in de verpleeghuisgeneeskunde en revalidatiegeneeskunde gewend is. Ook in de eerste lijn is het goed om zo veel mogelijk met een vast team (hometeam) te werken, zodat de hulpverleners op elkaar ingespeeld raken. Tevens is samenwerking met een vaste verpleeghuisarts en geriater/internist ouderengeneeskunde aan te bevelen. Zo ontstaat een geriatrisch zorgnetwerk. Niet alleen in verpleeghuizen, maar ook meer en meer in verzorgingshuizen worden MDO’s opgezet (multidisciplinair overleg). In zo'n MDO wordt gezamenlijk per patiënt een zorgplan opgesteld, wat vervolgens met de patiënt wordt besproken. Om de wensen en mogelijkheden van patiënten in verzorgingshuizen zo goed mogelijk in beeld te hebben wordt gewerkt met zogeheten EVV'ers (eerste verantwoordelijke verzorgenden) en 'contactverzorgenden'. Deze verzorgenden zijn het vaste aanspreekpunt voor een aantal patiënten in een verzorgingshuis.

\section{TOT SLOT}

Multimorbiditeit en polyfarmacie stellen de arts voor complexe vragen waarop niet altijd eenduidige antwoorden zijn te geven. De in dit hoofdstuk genoemde groepen patiënten zijn gebaat bij alertheid van de arts en een systematische werkwijze, met oog voor hun eigen inbreng. Dat maakt het geneeskundig proces bij deze patiënten boeiend en uitdagend.

\section{LITERATUUR}

Gezondheidsraad. Ouderdom komt met gebreken. Geneeskunde en zorg bij ouderen met multimorbiditeit. Nr. 2008-01. Den Haag: Gezondheidsraad, 2008.

Heijmans MJWM, Rijken PM, Schellevis FG, Bos GAM van den. Meer dan een ziekte. De gevolgen van comorbiditeit vanuit het perspectief van chronisch zieken en gehandicapten. Utrecht/Amsterdam: NIVEL/AMC, 2003.

Hertogh CMPM. Functionele geriatrie. Probleemgerichte zorg voor chronisch zieke ouderen. Maarssen: Elsevier/De Tijdstroom, 1999.

Nederlands Huisartsen Genootschap. Farmacotherapiebeleid in de huisartsenzorg. NHG-standpunt. Utrecht: NHG, 2008.

Nederlands Huisartsen Genootschap. Huisartsgeneeskunde voor ouderen. NHG-standpunt. Utrecht: NHG, 2007. 


\section{TABELLEN}

Tabel 13.1 Top vijf van combinaties van twee chronische ziekten bij personen van 55 jaar en ouder in de Nederlandse huisartsenpraktijk combinaties van chronische ziekte (prevalentie van de afzonderlijke ziekten) prevalentie van
combinatie (\%)
hypertensie $(29,9 \%) \&$ artrose $(27,2 \%)$
hypertensie $(29,9 \%) \&$ obesitas $(18,2 \%)$
artrose $(27,2 \%) \&$ cataract $(16,6 \%)$
hypertensie $(29,9 \%)$ \& diabetes mellitus $(14,6 \%)$
hypertensie $(29,9 \%)$ \& vetstofwisselingsstoornissen $(15,4 \%)$
Bron: Van Meeteren-Schram, e.a., 2008.

Tabel 13.2 Kans op ziekenhuisopname vanwege een geneesmiddelgerelateerd probleem in relatie tot het aantal aandoeningen

\begin{tabular}{|l|l|}
\hline aantal aandoeningen & OR $\mathbf{( 9 5} \% \mathbf{~ B I ) ~}$ \\
\hline Geen & 1,0 \\
\hline $1-2$ & $4,8(1,8-13,0)$ \\
\hline $3-4$ & $6,2(2,3-17,1)$ \\
\hline 5 of meer & $8,7(3,1-24,1)$ \\
\hline
\end{tabular}

Bron: HARM-studie, 2006.

Tabel 3 Top tien van chronisch gebruikte geneesmiddelgroepen bij polyfarmaciepatiënten

\begin{tabular}{|l|l|l|}
\hline geneesmiddelengroep & indicatie & $\begin{array}{l}\text { percentage } \\
\text { polyfarmaciepatiënten dat } \\
\text { dit middel gebruikt }\end{array}$ \\
\hline Antitrombotica & ischemische hart- en vaatziekten & $53 \%$ \\
\hline Bètablokkers & $\begin{array}{l}\text { angina pectoris en hoge } \\
\text { bloeddruk }\end{array}$ & $44 \%$ \\
\hline Statines & vetstofwisselingsstoornis & $42 \%$ \\
\hline Maagzuurremmers & klachten van maagzuur & $32 \%$ \\
\hline ACE-remmers & hoge bloeddruk en hartfalen & $29 \%$ \\
\hline orale bloedglucoseverlagende & diabetes mellitus & $24 \%$ \\
\hline middelen & slaapproblemen, nervositeit & $22 \%$ \\
\hline hypnotica en sedativa & hoge bloeddruk, hartfalen & $21 \%$ \\
\hline Anxiolytica & angst & $20 \%$ \\
\hline Calciumantagonisten & $\begin{array}{l}\text { angina pectoris en hoge } \\
\text { bloeddruk }\end{array}$ & $19 \%$ \\
\hline
\end{tabular}

Bron: Stichting Farmaceutische Kengetallen, 2004. 
Schellevis, F.G., Wind, A.W. Patiënten met multimorbiditeit en polyfarmacie. In: H.G.L.M. Grundmeijer; K. 7 Reenders; G.E.H.M. Rutten (Reds). Het geneeskundig proces. Klinisch redeneren van klacht naar therapite Maarssen: Elsevier gezondheidszorg, 2009. 329-341

Tabel 4 Voorbeelden van vaak ontbrekende geïndiceerde medicatie

\begin{tabular}{|l|l|l|}
\hline & $\begin{array}{c}\text { UMC } \\
\text { Utrecht* }\end{array}$ & VS** \\
\hline laxans bij morfine & $62 \%$ & - \\
\hline bètablokker na hartinfarct & $60 \%$ & $47 \%$ \\
\hline ACE-remmer bij hartfalen & $47 \%$ & $35 \%$ \\
\hline coumarine bij AF & $42 \%$ & $6 \%$ \\
\hline inadequate osteoporosetherapie & $29 \%$ & $30-70 \%$ \\
\hline statine bij hypercholesterolemie & $23 \%$ & $53 \%$ \\
\hline Antihypertensivum & $23 \%$ & $36 \%$ \\
\hline Ascal bij AP, MI, CVA/TIA & $21 \%$ & $34 \%$ \\
\hline maagbescherming bij NSAID & $21 \%$ & $89 \%$ \\
\hline
\end{tabular}

- Kuijpers, e.a., 2008. ** Higashi, 2004.

Tabel 5 Een voorbeeld van een zorgplan

\begin{tabular}{|c|l|l|l|l|l|}
\hline & probleem & Behandeldoel & actie & door wie & evaluatie \\
\hline S & $\begin{array}{l}\text { diabetes } \\
\text { mellitus }\end{array}$ & $\begin{array}{l}\text { acceptabele instelling } \\
\text { en schommelingen } \\
\text { beperken }\end{array}$ & $\begin{array}{l}\text { medicatie uitzetten } \\
\text { acceptatie dieet }\end{array}$ & $\begin{array}{l}\text { wijkverpleegkundige } \\
\text { praktijkondersteuner } \\
\text { eventueel diëtiste }\end{array}$ & 1 mnd \\
\hline S & artrose & $\begin{array}{l}\text { pijn draaglijk en } \\
\text { functiebehoud }\end{array}$ & pijnstilling & huisarts & 1 mnd \\
\hline F & duizeligheid & Valpreventie & $\begin{array}{l}\text { balansoefeningen } \\
\text { training spierkracht }\end{array}$ & fysiotherapeut & 4 mnd \\
\hline F & $\begin{array}{l}\text { moeizame } \\
\text { transfers } \\
\text { bed/stoel }\end{array}$ & $\begin{array}{l}\text { zelfstandig uit bed of } \\
\text { van de stoel opstaan }\end{array}$ & $\begin{array}{l}\text { aanvraag hoog/laag bed } \\
\text { + papegaai en sta-op- } \\
\text { stoel } \\
\text { oefenen transfers }\end{array}$ & $\begin{array}{l}\text { casemanager } \\
\text { fysiotherapeut }\end{array}$ & $4 \mathrm{mnd}$ \\
\hline M & eenzaamheid & dagelijks aanspraak & $\begin{array}{l}\text { aanmelding } \\
\text { dagbehandeling }\end{array}$ & casemanager & 4 mnd \\
\hline C & doofheid & $\begin{array}{c}\text { een-op-eengesprek } \\
\text { voeren }\end{array}$ & $\begin{array}{c}\text { verwijzing kno en } \\
\text { aanmeten gehoorprothese }\end{array}$ & huisarts & 4 mnd \\
\hline
\end{tabular}

